\title{
Profitability And Capital Structure Of Amex And Nyse Firms
}

Richard H. Fosberg, (Email: fosbergr@wpunj.edu), William Paterson University Arvin Ghosh, (Email: ghosha@wpunj.edu), William Paterson University

\begin{abstract}
In this study, we found that NYSE and AMEX firms have somewhat different capital structures. NYSE firms generally use 5\% to $8 \%$ more debt financing in their capital structures than AMEX firms. It was also found that the amount of debt in the capital structures of AMEX firms declined somewhat between 1985 and 2003 but remained relatively stable for NYSE firms. Also, NYSE firms were found to exhibit a strong inverse relationship between firm profitability and the amount on debt in the firm's capital structure. This result is generally consistent with Myers and Majluf's "asymmetric information theory" of capital structure. No relationship was found between profitability and capital structure for AMEX firms. Comparison of these results to similar calculations found in Fosberg and Ghosh (2005) for NASDAQ firms shows that, like AMEX firms, NASDAQ firms use less debt in their capital structures than NYSE firms and exhibit no relationship between profitability and capital structure. Consequently, because these anomalies exist for both $A M E X$ and NASDAQ firms, these two anomalies can not be an exchange listing effect.
\end{abstract}

\section{INTRODUCTION}<smiles>[CH]C1C=CCC=C1</smiles>

$\mathrm{n}$ a recent study, Fama and French (2001) showed that over the last twenty or so years a large number of companies have stopped paying dividends to their common stockholders'. Specifically, in $197866.5 \%$ of publicly traded firms paid dividends but by 1999 only $20.8 \%$ of such firms paid dividends. In analyzing their data, Fama and French conclude that part of the reason for the declining dividend payments has been a general reduction in the propensity of firms to pay dividends. One possible explanation for this reduction in the propensity to pay is that firms have decided to rely more on internally generated funds to finance their investment opportunities than they have in the past. Formally, this is the "pecking order theory" of firm capital structure suggested by Myers (1984) and Myers and Majluf (1984). Assuming the "pecking order theory" is the correct explanation of the dividend reductions firms will, among other things, also be using less debt capital to finance their investments than they have in the past. Fosberg and Ghosh (2005) tested this theory on a large sample of NYSE and NASDAQ firms and found that there had been a significant reduction in the amount of debt in the capital structures of NASDAQ firms over the last twenty years. NYSE firms did not exhibit any noticeable changes in capital structure over the period. At this point it is unclear if this difference in capital structure changes is due to firm size, exchange listing, or some other factor. Additionally, Fosberg and Ghosh found that there is a significant inverse relationship between firm profitability and the amount of debt in the firm's capital structure for NYSE firms, but not for NASDAQ firms.

In this study, we seek to extend previous research by ascertaining if the capital structure and profitability effects noted above extend to firms listed on the AMEX as well. We will also seek to determine what factors are causing these profitability and capital structure effects.

\section{DATA AND SAMPLE SELECTION}

Our base sample is all firms listed on the NYSE and AMEX stock markets that are reported on the COMPUSTAT data base (10-29-04 version). Firms in the utilities and financial services industries were eliminated from the base sample because of the potential biases associated with the heavy regulation of those industries. Companies with negative net worths in any sample year were also eliminated from the base sample because of the 
distorted capital structures of these firms. Outliers, firms with return on assets of more than $100 \%$ or less than $-100 \%$ in any sample year, were also eliminated from the base sample. This resulted in a final sample of 1022 NYSE and 244 AMEX firms. Data for each sample company for the sample years 1985, 1989, 1994, 1999, and 2003 was obtained from COMPUSTAT. Some companies did not have data for every sample year. Data for NASDAQ firms cited in this study came from Fosberg and Ghosh (2005). Previous studies such as Friend and Lang (1988) and Berger, Ofek, and Yermack (1997) have shown that the amount of debt in a firm's capital structure is affected by a number of factors including primarily firm size, risk, collateral availability, and growth opportunities. We will control for all of these factors in our analysis. Our firm size proxies are total assets (Assets), sales (Sales), and the market value of common equity (MVE). Collateral availability is measure by the firm's net property, plant, and equipment to total assets ratio (PPE). Growth opportunities are measured by the market to book value of common equity (MVE/BE) and Tobin's q. Tobin's q is calculated as the sum of the book values of debt and preferred equity plus the market value of common equity divided by the sum of the book values of debt, preferred, and common equity.

There are two well known theories that seek to explain the relationship between profitability and the amount of debt in a firm's capital structure. Jensen (1986) believes that greater profitability should result in more debt usage by firms in order to control the agency costs associated with free cash flow. Specifically, the increased debt service requirements caused by additional debt will force managers to pay out more of the firm's free cash flows to creditors and leave less money for managers to use for things that do not benefit the firm's shareholders. Jensen's theory implies a direct relationship profitability and the amount of debt in a firm's capital structure. Myers and Majluf (1984), however, argue that if there is asymmetric information in the capital markets, new security issues (debt and equity) will be undervalued by investors and the firm will be better off financing its investments with internally generated funds. Firms will, therefore, only finance with outside debt capital when internally generated funds are insufficient to fully fund the firm's investment opportunities. Myers and Majluf's theory implies an inverse relationship between profitability and the amount of debt in the firm's capital structure. Our empirical analysis should indicate which of these two theories is correct. Additionally, we will test to see if the relationship between firm profitability and the amount of debt in the typical firm's capital structure has changed over the last twenty years. Profitability is measured by sample year return on assets (ROA), return on equity (ROE), and operating cash flow divided by total assets (CF/Assets). Firm risk is measured by the standard deviation of ROA, ROE, and CF/Assets over the five year period from sample year $\mathrm{t}$ to year $\mathrm{t}-4$.

\section{RESULTS}

The mean values of selected variables for the AMEX sample firms for each of the sample years are presented in Table 1. Looking first at the size proxies, it is evident that the average size of AMEX firms grew only slightly over the sample period. For example, mean Assets grew from $\$ 254$ million in 1985 to only $\$ 318$ million in 2003. Also, there is a decrease in the amount of debt in the AMEX firms' capital structures over the sample period. The mean total debt to total assets ratio(Debt/Assets) declined from .208 in 1985 to .174 in 2003. Similarly, the mean total debt to total capital ratio (Debt/T. Cap.) dropped from .269 in 1985 to .232 in 2003 . Total capital is the sum of the book values of debt, preferred, and common equity. Interestingly, firm profitability has also decreased over the sample period. Mean ROA for the sample firms dropped from .049 (4.9\%) in 1985 to -.045 in 2003. Similar decreases in $\mathrm{ROE}$ and $\mathrm{CF} / \mathrm{Assets}$ are also evident. The data shows that AMEX firms' growth opportunities have increased over time as both mean MVE/BE and Tobin's q have risen over the sample period. Mean PPE increased from .274 in 1985 to .290 in 2003, indicating that AMEX firms have slightly more collateral available to pledge on debt than they used to.

NYSE firms display many, but not all, of the trends exhibited by AMEX firms (see Table 2). For example, mean Assets grew substantially over the sample period from $\$ 2,463$ million in 1985 to $\$ 8,678$ million in 2003. Also, comparing mean Assets figures, it is evident that the average NYSE firm is more than ten times larger than the average AMEX firm. The mean profitability of the NYSE firms has also declined over the sample period. For example, mean ROA declined from $.060(6.0 \%)$ in 1985 to .042 in 2003 . Other profitability measures exhibit a similar trend. Growth opportunities for NYSE firms have also increased as indicated by the increase in MVE/BE from 2.18 in 1985 to 2.69 in 2003. There has also been a slight decline in collateral availability (PPE) in recent years. The one trend that is different for NYSE firms relates to their capital structures. Examining the Debt/Assets ratio, the 
decrease in the amount debt in AMEX firms' capital structures is not evident for NYSE firms. In fact, there is no discernible trend in the capital structures of NYSE firms. However, the typical NYSE firm has, on average, more debt in its capital structure in each sample year than the average AMEX firm (5\% more over the last decade).

Our next objective is to test for the relationship, if any, between firm profitability and capital structure and to see if this relationship has changed over time. This will be accomplished with a regression analysis in the which the firm's Debt/Assets ratio is used as the dependent variable. A separate regression will be run for each sample year. In each regression, control variables for firm size, collateral, growth opportunities, and risk will be employed.

Table 1: Summary Statistics for Selected Variables for the AMEX Firms

\begin{tabular}{|c|c|c|c|c|c|}
\hline \multicolumn{6}{|c|}{ Panel A: Firm Size } \\
\hline & $\underline{1985}$ & $\underline{1989}$ & $\underline{1994}$ & $\underline{1999}$ & $\underline{2003}$ \\
\hline Assets (\$M) & 254 & 364 & 607 & 320 & 318 \\
\hline Sales (\$M) & 269 & 313 & 296 & 328 & 361 \\
\hline MVE (\$M) & 196 & 358 & 200 & 199 & 355 \\
\hline \multicolumn{6}{|c|}{ Panel B: Capital Structure } \\
\hline Debt $(\$ M)$ & 53 & 97 & 78 & 104 & 103 \\
\hline Debt/Assets & .208 & .237 & .194 & .228 & .174 \\
\hline Debt/T. Cap. & .269 & .301 & .256 & .299 & .232 \\
\hline \multicolumn{6}{|c|}{ Panel C: Profitability, Growth, etc. } \\
\hline ROA & .049 & .021 & .013 & -.009 & -.045 \\
\hline ROE & .076 & .036 & .032 & .002 & -.067 \\
\hline $\mathrm{CF} /$ Assets & .126 & .098 & .088 & .051 & .012 \\
\hline MVE/BE & 2.41 & 1.86 & 2.00 & 3.01 & 3.26 \\
\hline Tobin's q & 1.09 & 1.61 & 1.77 & 2.71 & 3.00 \\
\hline PPE & .274 & .300 & .313 & .315 & .290 \\
\hline
\end{tabular}

$\mathrm{M}=$ million

The main independent variables of interest are profitability measures (ROA and Avg. ROA). ROA measures current year profitability while Avg. ROA (average annual ROA over years t to $t-4$ ) measures long-term profitability. In Table 3, the results of the regressions for AMEX firms are presented. In these regressions, firm size (Assets) is weakly correlated with the amount of debt in the sample firms' capital structures. In four of the sample year regressions, the coefficient of Assets is positive but not significant at conventional levels. Collateral availability is shown to be a significant determinant of firm capital structure. The coefficients of PPE are all positive and two are significant at the $10 \%$ level or better. Four of the coefficients of Tobin's q are negative and three of these are significant at the $10 \%$ level or better. This indicates that high growth firms tend to use less debt in their capital structures than low growth firms. Firm risk does not seem to be an important determinant of firm capital structure as the coefficients of Std. ROA do not have a consistent sign. The relationship between firm profitability and capital structure is also weak, at best. Looking at current year's profitability (ROA), only one coefficient is statistically significant at conventional levels and the signs of the coefficients are not consistent. For long-term profitability (Avg. ROA), the coefficients are again inconsistent in their signs. In sum, these results indicate there is little or no relationship between firm profitability and the amount of debt in AMEX firms' capital structures. 
Other dependent and control variables were also tried in the above regressions (not shown). Sales and MVE were tried as size proxies and $\mathrm{ROE}$ and $\mathrm{CF} /$ Assets were used as profitability measures. Additionally, MVE/BE was employed as a growth proxy and Debt/T. Cap. was substituted as the capital structure proxy. None of these variables improved on the explanatory power of the regressions reported above.

Table 2: Summary Statistics for Selected Variables for the NYSE Firms

\begin{tabular}{|c|c|c|c|c|c|}
\hline \multicolumn{6}{|c|}{ Panel A: Firm Size } \\
\hline & $\underline{1985}$ & $\underline{1989}$ & $\underline{1994}$ & $\underline{1999}$ & $\underline{2003}$ \\
\hline Assets (\$M) & 2463 & 4075 & 4767 & 6247 & 8678 \\
\hline Sales $(\$ M)$ & 2830 & 3759 & 4297 & 5450 & 7163 \\
\hline $\operatorname{MVE}(\$ M)$ & 1868 & 2808 & 3508 & 9074 & 8416 \\
\hline \multicolumn{6}{|c|}{ Panel B: Capital Structure } \\
\hline Debt $(\$ M)$ & 536 & 1355 & 1399 & 1929 & 2571 \\
\hline Debt/Assets & .215 & .251 & .230 & .269 & .239 \\
\hline Debt/T. Cap. & .296 & .346 & .327 & .373 & .344 \\
\hline \multicolumn{6}{|c|}{ Panel C: Profitability, Growth, etc. } \\
\hline ROA & .060 & .062 & .062 & .054 & .042 \\
\hline ROE & .115 & .128 & .131 & .127 & .092 \\
\hline $\mathrm{CF} /$ Assets & .164 & .160 & .161 & .153 & .133 \\
\hline MVE/BE & 2.18 & 2.30 & 2.55 & 3.16 & 2.69 \\
\hline Tobin's q & 1.88 & 1.89 & 2.08 & 2.42 & 2.08 \\
\hline PPE & .368 & .368 & .374 & .356 & .338 \\
\hline
\end{tabular}

Table 4 contains the results of a similar regression analysis performed on NYSE firms. Four of the coefficients of Assets are positive and significant at the 5\% level or better. Also, the coefficients of PPE are all positive and four are significant at the $5 \%$ level or better. The coefficients of Tobin's q are all negative and significant at the $1 \%$ level. For Std. ROA, the coefficients are all negative and four are significant at the $1 \%$ level. These results are much stronger for the NYSE firms than they were for the AMEX firms. In general, these regressions indicate that there are strong relationships between firm size (direct), collateral availability (direct), growth opportunities (inverse), and firm risk (inverse) and the amount of debt in a firm's capital structure for NYSE firms. Another significant difference between the two sets of regressions relates to firm profitability. While there was little or no relationship between profitability and capital structure for AMEX firms, there is a strong inverse relationship for NYSE firms. For NYSE firms, four of the coefficients of ROA are negative and significant at the $1 \%$ level. For Avg. ROA, the coefficients are all negative and three are significant at the $1 \%$ level. These results indicate that the amount of debt in NYSE firms' capital structures is inversely related to both current and long-term profitability. This result is consistent with Myers and Majluf”s "asymmetric information theory” of capital structure.

To this point, two of the main results of this study are that NYSE firms have more debt in their capital structures than AMEX firms and that profitability and capital structure are inversely related for NYSE firms but not for AMEX firms. These findings will be further tested in a regression analysis in which both NYSE and AMEX firms are included in each sample year's regression. This will allow us to test for the statistical significance of the above findings. This will require that two new independent variables be employed. The first is NasdD, a dummy variable 
that takes on a value of one if the sample firm is a AMEX firm and zero otherwise. The coefficient of this dummy variable will indicate whether there is a difference in the amount of debt in the capital structures of the two

Table 3: Regression Analysis of Capital Structure for AMEX Firms

\begin{tabular}{|c|c|c|c|c|c|}
\hline & $\underline{1985}$ & $\underline{1989}$ & $\underline{1994}$ & $\underline{1999}$ & $\underline{2003}$ \\
\hline $\begin{array}{l}\text { Intercept } \\
\quad(\mathrm{t} \text { value })\end{array}$ & $\begin{array}{l}.237 \mathrm{c} \\
(4.68)\end{array}$ & $\begin{array}{l}.344 c \\
(6.88)\end{array}$ & $\begin{array}{c}.216 \mathrm{c} \\
(5.53)\end{array}$ & $\begin{array}{c}.248 c \\
(7.25)\end{array}$ & $\begin{array}{l}.170 \mathrm{c} \\
(8.19)\end{array}$ \\
\hline Assets $\left(10^{4}\right)$ & $\begin{array}{l}.014 \\
(0.13)\end{array}$ & $\begin{array}{l}.015 \\
(0.18)\end{array}$ & $\begin{array}{l}-.013 \\
(-0.48)\end{array}$ & $\begin{array}{l}.071 \\
(1.03)\end{array}$ & $\begin{array}{l}.080 \\
(1.64)\end{array}$ \\
\hline PPE & $\begin{array}{c}.051 \\
(0.49)\end{array}$ & $\begin{array}{l}.018 \\
(0.18)\end{array}$ & $\begin{array}{l}.136 a \\
(1.72)\end{array}$ & $\begin{array}{l}.025 \\
(0.41)\end{array}$ & $\begin{array}{l}.149 c \\
(3.16)\end{array}$ \\
\hline Tobin's q & $\begin{array}{l}-.001 \\
(-0.06)\end{array}$ & $\begin{array}{c}.001 \\
(0.03)\end{array}$ & $\begin{array}{l}-.019 \mathrm{a} \\
(-1.83)\end{array}$ & $\begin{array}{l}-.018 c \\
(-3.14)\end{array}$ & $\begin{array}{l}-.014 c \\
(-4.28)\end{array}$ \\
\hline ROA & $\begin{array}{l}-1.76 \mathrm{c} \\
(-5.30)\end{array}$ & $\begin{array}{l}-.435 \\
(-1.32)\end{array}$ & $\begin{array}{c}.215 \\
(1.15)\end{array}$ & $\begin{array}{c}.278 \\
(-1.06)\end{array}$ & $\begin{array}{l}-.048 \\
(-0.49)\end{array}$ \\
\hline Avg. ROA & $\begin{array}{l}.889 \mathrm{~b} \\
(2.19)\end{array}$ & $\begin{array}{l}-.900 b \\
(-2.10)\end{array}$ & $\begin{array}{l}-.503 a \\
(-1.77)\end{array}$ & $\begin{array}{l}-.344 \\
(-1.39)\end{array}$ & $\begin{array}{c}.052 \\
(0.53)\end{array}$ \\
\hline Std. ROA & $\begin{array}{l}.246 \\
(0.45)\end{array}$ & $\begin{array}{l}-1.62 c \\
(-3.24)\end{array}$ & $\begin{array}{l}-.498 b \\
(-2.01)\end{array}$ & $\begin{array}{l}.096 \\
(0.44)\end{array}$ & $\begin{array}{c}.032 \\
(0.46)\end{array}$ \\
\hline Adj. $R^{2}$ & .23 & .12 & .08 & .04 & .13 \\
\hline$F$ value & $5.30 \mathrm{c}$ & $3.20 \mathrm{c}$ & $2.65 \mathrm{~b}$ & $2.14 \mathrm{a}$ & $6.29 \mathrm{c}$ \\
\hline
\end{tabular}

$\mathrm{a}=$ significant at the $10 \%$ level

$\mathrm{b}=$ significant at the $5 \%$ level

$\mathrm{c}=$ significant at the $1 \%$ level

groups of firms. The second new variable is ROA-NasdD (ROA multiplied by NasdD), an interactive dummy variable that will indicate whether there is a difference in the relationship between profitability and firm capital structure for the two groups of sample firms. The results of these regressions are presented in Table 5. The coefficients of Assets, PPE, Tobin's q, Std. ROA, ROA, and Avg. ROA are similar to those reported previously in Table 4. The coefficient of NasdD is negative in four years and three of those are significant at the $1 \%$ level. This indicates that, on average, AMEX firms use less debt in their capital structures than NYSE firms. The coefficients show that after controlling for firm size, profitability, etc. AMEX firms have averaged 5\% to $8 \%$ less debt in their capital structures than NYSE firms over the last decade. Four of the coefficients of ROA-NasdD are positive and three of those are significant at the $1 \%$ level. This indicates that there is a statistically significant difference in the relationship between profitability and capital structure for the two groups of sample firms. The coefficient of ROA shows this relationship for NYSE firms and indicates a statistically significant inverse relationship between profitability and capital structure in all sample years. The sum of the coefficients of ROA and ROA-NasdD shows the relationship between profitability and capital structure for AMEX firms. For example, for 2003 the sum of the coefficients is $.137(-.178+.315)$. Since .137 is not statistically significant at conventional levels $(\mathrm{t}=0.95)$, this means that there is no relationship between profitability and capital structure for AMEX firms in 2003. Overall, the sum of the coefficients is positive in the last three sample years (one is significant) and negative in the first two 
sample years (both are significant). In sum, the erratic signs of the coefficient sums indicate there is no consistent relationship between profitability and capital structure for AMEX firms.

Table 4: Regression Analysis of Capital Structure for NYSE Firms

\begin{tabular}{|c|c|c|c|c|c|c|}
\hline & & $\underline{1985}$ & $\underline{1989}$ & $\underline{1994}$ & $\underline{1999}$ & $\underline{2003}$ \\
\hline $\begin{array}{l}\text { Intercept } \\
\text { (t value) }\end{array}$ & & $\begin{array}{l}.262 \mathrm{c} \\
(14.5)\end{array}$ & $\begin{array}{l}.339 \mathrm{c} \\
(18.5)\end{array}$ & $\begin{array}{l}.298 c \\
(19.4)\end{array}$ & $\begin{array}{l}.321 \mathrm{c} \\
(25.8)\end{array}$ & $\begin{array}{l}.298 \mathrm{c} \\
(25.2)\end{array}$ \\
\hline Assets $\left(10^{4}\right)$ & -.010 & $\begin{array}{c}.013 \mathrm{c} \\
(-1.18)\end{array}$ & $\begin{array}{l}.008 \mathrm{~b} \\
(3.00)\end{array}$ & $\begin{array}{l}.005 \mathrm{~b} \\
(2.55)\end{array}$ & $\begin{array}{l}.004 \mathrm{c} \\
(2.18)\end{array}$ & $(3.33)$ \\
\hline PPE & & $\begin{array}{l}.127 \mathrm{c} \\
(3.77)\end{array}$ & $\begin{array}{c}.049 \\
(1.58)\end{array}$ & $\begin{array}{l}.059 \mathrm{~b} \\
(2.41)\end{array}$ & $\begin{array}{c}.092 \mathrm{c} \\
(4.26)\end{array}$ & $\begin{array}{l}.107 \mathrm{c} \\
(5.59)\end{array}$ \\
\hline Tobin's q & & $\begin{array}{l}-.017 \mathrm{c} \\
(-2.86)\end{array}$ & $\begin{array}{l}-.020 \mathrm{c} \\
(-2.71)\end{array}$ & $\begin{array}{l}-.018 \mathrm{c} \\
(-3.11)\end{array}$ & $\begin{array}{c}-.010 \mathrm{c} \\
(-5.17)\end{array}$ & $\begin{array}{l}-.020 \mathrm{c} \\
(-4.98)\end{array}$ \\
\hline ROA & & $\begin{array}{l}-.472 \mathrm{c} \\
(-3.28)\end{array}$ & $\begin{array}{l}-.862 \mathrm{c} \\
(-5.33)\end{array}$ & $\begin{array}{l}-.628 c \\
(-4.57)\end{array}$ & $\begin{array}{l}-.317 \mathrm{c} \\
(-2.82)\end{array}$ & $\begin{array}{c}.006 \\
(0.06)\end{array}$ \\
\hline Avg. ROA & & $\begin{array}{l}-.272 \\
(-1.35)\end{array}$ & $\begin{array}{l}-.029 \\
(-0.16)\end{array}$ & $\begin{array}{l}-.354 \mathrm{c} \\
(-2.73)\end{array}$ & $\begin{array}{l}-.647 \mathrm{c} \\
(-5.47)\end{array}$ & $\begin{array}{l}-.728 c \\
(-5.64)\end{array}$ \\
\hline Std. ROA & & $\begin{array}{l}-.683 c \\
(-3.45)\end{array}$ & $\begin{array}{l}-.768 c \\
(-4.06)\end{array}$ & $\begin{array}{l}-.071 \\
(-0.53)\end{array}$ & $\begin{array}{l}-.356 c \\
(-3.14)\end{array}$ & $\begin{array}{l}-.793 c \\
(-6.07)\end{array}$ \\
\hline Adj. $R^{2}$ & & .21 & .24 & .24 & .21 & .19 \\
\hline F value & & $21.7 \mathrm{c}$ & $28.5 \mathrm{c}$ & $34.7 \mathrm{c}$ & $38.6 \mathrm{c}$ & $37.9 \mathrm{c}$ \\
\hline
\end{tabular}

$\mathrm{a}=$ significant at the $10 \%$ level

$\mathrm{b}=$ significant at the $5 \%$ level

$\mathrm{c}=$ significant at the $1 \%$ level

Fosberg and Ghosh (2005) did an analysis of NASDAQ firms for the same sample years used in this study and found results similar to those that we report for AMEX firms. For example, NASDAQ firms have mean Assets over the sample years of $\$ 574$ million versus $\$ 373$ million for AMEX firms. Thus, AMEX and NASDAQ firms are of approximately the same size whereas NYSE firms are much larger (mean Assets of $\$ 5,246$ million). NASDAQ firms also experience a similar decline in the amount of debt in their capital structures (from Debt/Assets of .204 in 1985 to .141 in 2003) as noted above for AMEX firms. Also, NASDAQ firms are found to exhibit no relationship between firm profitability and the amount of debt in their capital structures. The similarity of these results suggests several implications. First, the lack of a relationship between profitability and capital structure is not an exchange listing phenomenon as it is apparent for both NASDAQ and AMEX firms. Similarly, the lower debt usage by both NASDAQ and AMEX firms can not be an exchange listing phenomenon. This results of this study do not suggest what the cause of these anomalies might be and, therefore, that is left to future research.

\section{CONCLUSION}

In this study, we found that NYSE and AMEX firms have somewhat different capital structures. NYSE firms generally use 5\% to $8 \%$ more debt financing in their capital structures than AMEX firms. It was also found that the amount of debt in the capital structures of AMEX firms declined somewhat between 1985 and 2003 but remained 


\section{REFERENCES}

1. Berger, P., E. Ofek, and D. Yermack, (1997), Managerial Entrenchment and Capital Structure Decisions, Journal of Finance, Vol. 52 No. 4, pp.1411-38.

2. Fama, E. and K. French, (2001), Disappearing Dividends: Changing Firm Character tics or Lower Propensity to Pay, Journal of Financial economics, Vol. 60, 3-43.

3. Fosberg, R. and A. Ghosh, (2005), Capital Structure Changes in NYSE and NASDAQ Firms, Working Paper, William Paterson University.

4. Friend, I. and L. Lang, (1988), An Empirical Test of the Impact of Managerial Self-Interest on Corporate Capital Structure, Journal of Finance, Vol. 43 No. 2, pp.271-81.

5. Jensen, M. Agency Costs of Free Cash Flow, Corporate Finance, and Takeovers. American Economic Review, 76 (1986), 323-329.

6. $\quad$ Myers, S. (1984), The Capital Structure Puzzle, Journal of Finance, Vol. 39 No. 3, 575-92.

Myers, S. and N. Majluf, (1984), Corporate Financing and Investment Decisions When Firms Have Information That Investors Do Not Have, Journal of Financial Economics, vol. 13, 187-221. 